\title{
参考資料
}

\section{湿り排ガス中のばいじん濃度測定における問題点 とその考え方}

On the Problem in Measurement of Dust Concentration in Wet Flue Gas

\section{1.はじめに}

一時減少傾向のみられた都市大気中の浮遊粉じんは, 図 11にみるようにここ数年再び増加現象を示してい る。この浮遊じんと亜硫酸ガスその他の有害ガスとが共 存して，人体への悪影響を相乗させることが認識されだ して,ばいじん, 粉じんへの対策は一層強く叫ばれるこ とになった。

1971年 6 月, 法改正に伴い改定された「大気污染防止 法施行規則」(以下「施行規則」と略称) では, 従来の各 発生施設に和けるばいじん排出基準の值が約 1/3〜1/10 に規制強化され, 加兄て, 大気污染が強度に進行してい る大都市では,さらに厳しい特別排出基準が定められ た。また, 従来はなかった粉じん一一物の破砕, 選別等 に伴い発生するもの, 原料ヤード等から飛散するもの 一についても，新たに構造，使用，管理に関する規制 が加えられることになった。

こうした法規制強化に伴い，ばいじん濃度測定に対す

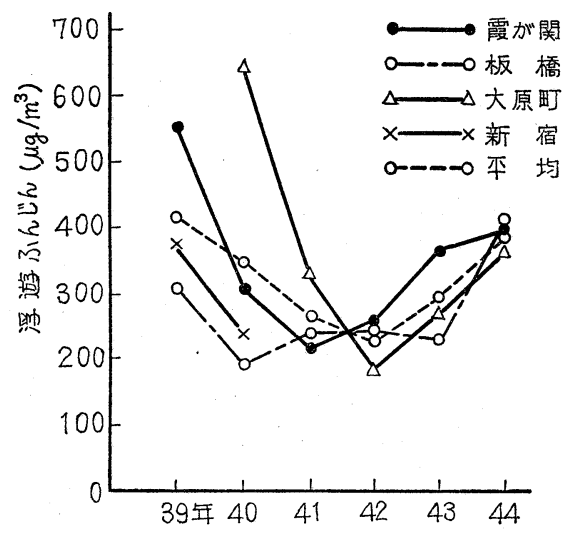

図 1 東京都内 3 力所の浮遊じん濃度の経年変化 ${ }^{1}$

昭和46年10月 22 日受理

* 工業技術院 公害資源研究所（干115 東京都北区浮間町4-26） TEL 03-960-7151

\section{田森 行 男* Ikuo Tamori}

る関心は高まり, 従来の測定法に対する異議もいろいろ 昌えられている。表題の湿り排ガス中のばいじん濃度測

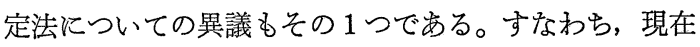
の排出基準はノルマル状態に和けるかわき基準で規定さ れているが，たとえば湿式集じん処理後の排ガス測定で は，水分百分率がきわめて高いので，ばいじん濃度とし ては実際よりもさわめて高い值となったり，值の変動が 大きい結果となることがある。この問題について若干検 討したのでここに紹介し，あわせて測定法についての私 見を述べたい。

\section{2. 現行の表示法とその法的根拠}

\section{1 大気污染防止法之同施行規則}

大気污染防止法の第 3 条では，「排出基準は，ばい煙 発生施設に和いて発生するばい煙について，厚生省令， 通商産業省令で定める」とし，この規定に従い「施行規 則」の第 4 条では,「…..ばいじんの排出基準は,温度が 零度であう், 它方方 $\dot{i}$ 気庄方状態換算した排出ガス 1 立方メートルにつき，別表第 2 の第 2 欄に揭げる施設 の種類および同表の第 3 欄に掲げる規模ごとに同表の第 4 欄に揭げるばいじんの量とする。」(傍点は筆者)とし た。さらに同第15条第 3 項で「ばいじんに係るばい煙濃 度の測定は，別表第 $\dot{2}$ の備考に揭げる測定法により，2 月を越えない作業期間ごとに 1 回以上（ばい煙発生施設 に拈いて発生し，排出口から大気中に排出される排ガス 量が毎時40,000立方メートル未満のばい煙発生施設に係 る測定については年 2 回以上）行なうこと。」としてい る。そして「別表第 2 の備考」ではばいじん量は，「…... ばいじん量は，規格 $\dot{Z}$ 8808ほ定める方法方方測定さ れる量として表示されたものとし，…..」(傍点いずれる 筆者）となっている。

すなわら，「施行規則」では， $0^{\circ} \mathrm{C} ， 1$ 気圧のノルマル 状態を基準とした排ガス $1 \mathrm{~m}^{3}$ あたりのばいじん量とし て表わされることだけを規定し，以下の細目はJIS の規 定，「煙道排ガス中のばいじん量の測定方法」に譲って 
いる。

\subsection{JIS Z 8808}

この JIS の，「第 9 章 ばいじん濃度の計算」を少し 紹介しよら。

\section{「9.1 かわき排ガス中のばいじん濃度}

基準状態 $\left(0^{\circ} \mathrm{C}\right.$, 気圧 $\left.760 \mathrm{mmHg}\right)$ に換算したかわさ排 ガス $1 \mathrm{~m}^{3}$ に含まれるばいじんの質量で表わし,つぎの 式によって求める。

$$
W=\frac{m}{V_{N}{ }^{\prime}}
$$

ここに，W：かわき排ガス中のばいじん濃度 $\left(\mathrm{g} / \mathrm{Nm}^{3}\right)$

$m$ ：捕集したばいじん質量（g）

$V_{N}{ }^{\prime}$ : 基準状態に和ける吸引したかわきガス量 $\left.\left(N m^{3}\right)\right\rfloor$

な秝，ここで $V_{N}{ }^{\prime}$ とてていのは，次式で計算できる。

$$
V_{N}{ }^{\prime}=V \times \frac{273}{273+\theta_{m}} \times \frac{P_{a}+p_{m}-P_{v}}{1760} \times 10^{-3}
$$

ここに，V: 吸引した湿りガス量（湿式ガスメータの読 み) $(l)$

$$
\begin{aligned}
& \theta_{m}: \text { ガスメータに护ける吸引ガス温度 }\left({ }^{\circ} \mathrm{C}\right) \\
& \left.P_{a}: \text { 大気圧 ( } \mathrm{mmHg}\right) \\
& p_{m}: \text { ガスメータに拉けるガスのゲージ圧 }
\end{aligned}
$$$$
(\mathrm{mmHg})
$$

$P_{v}: \theta_{m}$ の飽和水蒸気圧 $(\mathrm{mmHg})$

すなおち, JIS に捇いて, normal base に加えて dry base を規定して括り，「施行規則」の排出基準值はその 別表第 2 の備考の叙述により, いずれもこの dry base の規定に従らことになる。

しかしながら，そもとも JIS Z 8808 は，高温度の燃 焼排ガスを対象として作られて, 後, 機械的処理に伴う 粉じんの濃度測定その他にも援用できることになったも のであって，ここで問題にしているよらな水分量のきわ めて多い場合のばいじんについては，想定していなかっ たのではないかという疑問が生まれる。

\section{3. 現行の規定から生ずる問題}

\section{1 水分量がきわめて高い場合}

水分量は, JIS Z 8808 では, volume base の百分率 で規定している。つまり水分量 $x_{w}$ は,

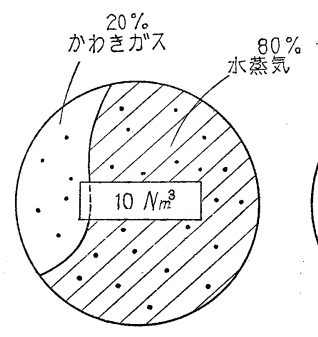

a)

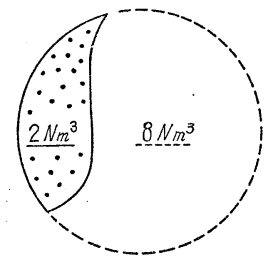

b)
图 2 排ガス中ばいじんの説明図

$$
x_{w}=\frac{\text { 水蒸気の容量 } \times 100}{\text { かわきガスの容量十水蒸気の容量 }}
$$

で規定される。したがって, 水蒸気の容量がきわめて大 きい場合には，実際の煙道，ダクト中の濃度よりも， dry base のばいじん濃度は濃縮された形となって, 相 当高い值として計算される。たとえば，図 2,a)のよう な $10 \mathrm{Nm}^{3}$ のガス中に水分量が $80 \%$ 存在し，ばいじんは $20 \mathrm{~g}$ の量が均等に分布していたとする。a) の状態では ばいじん濃度は $20 / 10=2 \mathrm{~g} / \mathrm{Nm}^{3}$ ¿である。一方の b) で は, $80 \%$ の水蒸気が完全に凝縮して，その中に含まれて いたばいじんは20\%の dry gas の中に移行した場合で ありばいじん濃度は $20 / 2=10 / \mathrm{Nm}^{3}$ とはねあがる。こ の值は, 煙道中のばいじんの実態を正しく反映していな い,といら異論である。

\section{2 水滴によるばいじん濃度測定值の変動}

水分量の測定は, 一定量の排ガスを吸引して吸湿管に 導き, 水蒸気を完全に吸湿または凝縮させて, 増加した 分を科量して計算する。したがって，水分が完全に気化 している場合には，この方法ではかなりの精度で水分百 分率をらることができる。ところが，気化しきれていな いで，水滴 (ミスト) を伴うガスの場合は問題である。 1 滴のミストでも吸湿管に混入するなら，それの換算さ れた蒸気量は相当大きい值になるからである。これを避 けるため，いま JIS 化を準備中の「排ガスの試料採取 方法」で例示している図 3 e) 和よびf) が活用できる。 もっとも, これにしても, 微小なミストの混入を完全に 避けることはできない。この点ではむしろ，100다 以下 の温度の排ガス中に水滴が混在している場合は, 水分は 飽和水蒸気圧に達しているものとみなし, 測定によらず に計算によって水分量を求めてよいと考えられる。

湿式集じん装置後の排ガス中ばいじん濃度測定におい ては, しばしば值の変動の大きいことが報告されてい る。その理由としては，可溶性ばいじんの評価や，ばい 


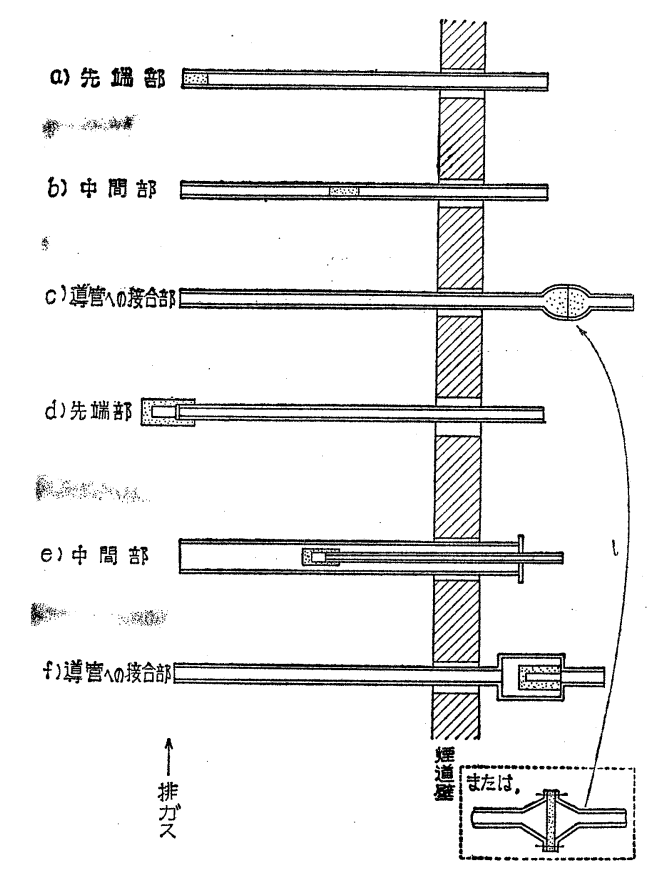

図 3 水分測定に持けるダストの分離方法

じんを含んだ氷滴のばいじんサンプラへの流入も影響し ようが, 上述の水分測定值の変動も大きい要因と思われ る。

\section{4. 表示法に関する考え方}

\section{1 従来のばいじん濃度 $W$ に水分補正を施す方法}

$$
W^{\prime}=\frac{m}{V_{N}}=\left(1-\frac{x_{w}}{100}\right) W
$$

ここに, $V_{N}$; 基準状態に和ける四引した湿りガス量

上式は(1)式の定義からあきらかなつぎの関係から求めら れる。

$$
V_{N}^{\prime}=V_{N}\left(1-\frac{x_{w}}{100}\right)
$$

この考兄方は，「施行規則」に規定する normal base には従っているが, JIS の dry base には従わず, wet base そ基づくるのである。図 2 の例でみるなら，a）の $2 \mathrm{~g} / \mathrm{Nm}^{3}$ の濃度々のままの形で表現されるものである。

\section{2 排ガス中の状態そのもので表わす方法}

$$
W^{\prime \prime}=\left(1-\frac{x_{w}}{100}\right) \times \frac{P_{a}+p_{s}}{760} \times \frac{760}{273+\theta_{s}} \times W
$$

Vol. 9 No. 1 (1972)

\section{ここに， $p_{s} ;$ 煙道ガスの静圧 $\quad(\mathrm{mmHg})$ \\ $\theta_{s} ;$ 煙道ガスの温度 $\quad\left({ }^{\circ} \mathrm{C}\right)$}

湿式処理後の排ガスは冷却されて, 数十度といった低 い温度になる場合が多い。とすれば，ことさら normal base 飞換算しないで，その排ガスの状態に扔いて表示 した方が実態に即していないか，という考光によるもの で「施行規則」の normal base に従っていない。

\section{3 排ガスが大気中に拡散する状態で表示する方法}

$$
W^{\prime \prime \prime}=\left(1-\frac{x_{w}}{100}\right) \times \frac{P_{a}}{760} \times \frac{273}{273+\theta_{a}} \times W
$$

\section{ここに, $\theta_{a} ;$ 大気温度 $\left({ }^{\circ} \mathrm{C}\right)$}

「施行規則」のnormal base には基づかないが，大気 の状態を base にする点は, 大気污染との関連で妥当に みえる。しかし，(7)式は排ガス中水分がとのまま蒸気と して大気中に拡散した場合を想定しており，これは必ず しも実態に即しない。寒態に合わせるには，そのときの 大気湿度, 温度との関連で凝縮する部分を正しくは握 しあわせてその凝縮水滴中のばいじんをる評価しなけ ればならないが，これは実際上推定して式で表現するこ とが不可能である。

\section{4 現行表示法}

(4)，(6)式の考方方は，湿式処理によって排分え中に水 蒸気を多量に加兄，濃度を薄めたことを容認したことに なり, 大気污染の抑制といら基本的観点からは逆行する ものである。

また，湿式処理後の排ガスの場合だけを，wet base にするとか，normal base をやめるなどと特別报したす ることは，かえって無用の混乱を招くことになり，好ま しくない。

\section{5. 測定方法}

湿式処理後の排ガス測定では，気化された水分量がき わめて多く，また往々にして大量の水滴が混在するた め, JIS Z 8808 の規定通りの測定が困難な場合が多い。 サンプラとして，ダストチニーブではきわめて抵抗が大 きく，吸引量を十分に大きく取れないことがあり，“セル ローズ製ろ紙では，吸湿性が強く破損しやすいという問 題がある。

そこで，筆者自身の経験から，つぎの方法を推奖した い。 


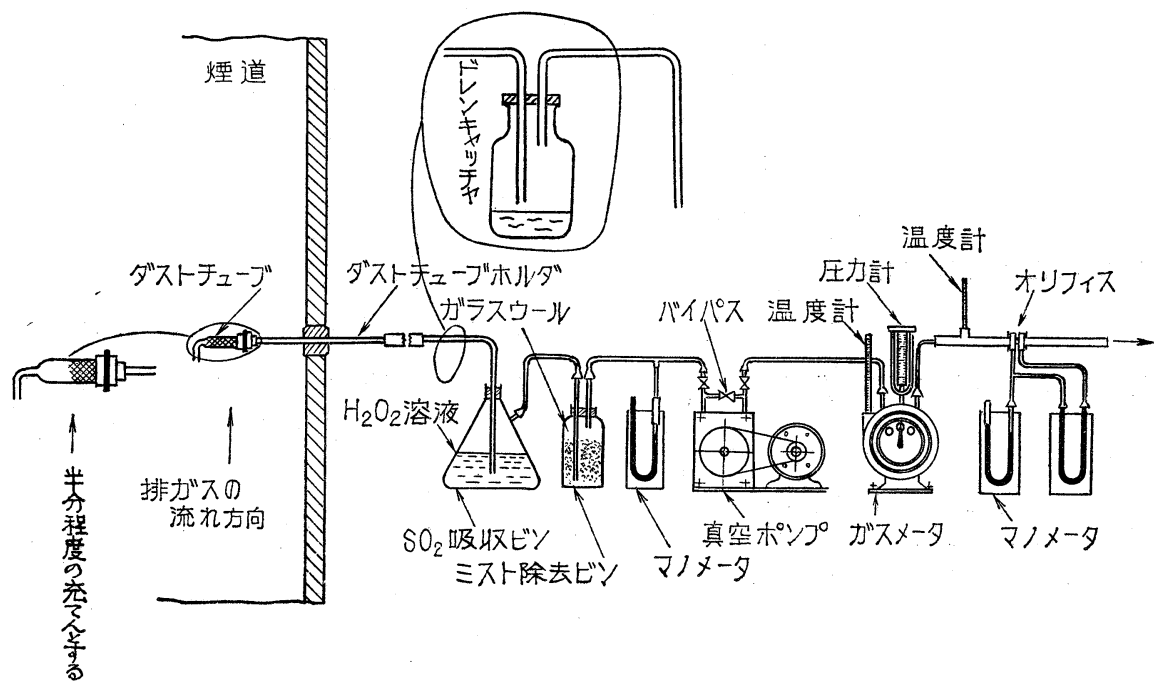

図 4 ダストチューブによる測定装置の一例

\section{1 ダストチュープ法}

通常用いるダストチューブへのグラスウール充てん量 を半分位に減らして抵抗を下げ，図4 のように $\mathrm{SO}_{2}$ 吸 収ビンの前にドレンキャッチャを設けて，ダストチュー ブ内の水分が吸引されるさいに，同伴される可能性のあ るばいじん，および可溶性ばいじんをドレンキャッチャ で捕集し，これを蒸発乾固して科量に加える方法であ る。

ダストチューブ内のグラスウール充てん密度は, JIS では $0.25 \mathrm{~g} / \mathrm{ml}$ 程度, 充てん長さは $50 \sim 180 \mathrm{~mm}$ と規定し ているが，筆者らの実験的研究 23 から，100mmの充てん 長さとしても, 大抵のばいじんは $99 \%$ 以上捕集できるこ とが確かめられている。加えてこの場合には，グラスウ 一ル中に保持される水分がばいじんの捕集率を高めるた め, 99\%以上の捕集率は問題ないと考兄られる。

\section{2 円筒万紙法}

筆者らはさきに, ばいじんのサンプラとして, ガラス 繊維製円筒ろ紙の使用を提唱した ${ }^{32}$ 。 最近, 普及の著し いガラス繊維製ろ紙の耐熱性と小さい吸湿性に着目した 結果である。このガラス繊維製円筒ろ紙の背後に, 円筒 型金網を設けて補強することにより，ろ紙の破損を防止 しつつ水分量の大きいガスを吸引することができる。こ の場合も，やはり図4のようにドレンキャッチャを設 ケ，可溶性のばいじんもあわせ科量することが望まし w。

\section{6. むす び}

水滴が存在する排ガス中ばいじん量測定の問題点とそ の考方について述べた。4で述べた幾つかの異なる考 え方について紹介したが，広く検討していただき，御意 見を寄せていただければさいわいである。るし筆者に, このらちのいずれを採るかをしいて問われるならば,こ れらの測定の本来の目的である大気污染防止の観点から して，4.4の現行通りと答えたい。しかし，こうした混 乱は, 現行の排出基準が濃度規制であるところから生ず るのであって, 全い括ら酸化物の規制に括いて一歩前進 したように排出総量規制でいくなら，こうした異議は起 こらないであろう。

水滴の存在する場合のもう 1 つの大きな問題は, 排ガ ス中に $\mathrm{SO}_{3}$ が存在する場合である。ガス中の水分と結合 して $\mathrm{H}_{2} \mathrm{SO}_{4}$ が生成した場合, 実は 5 で述べた測定法で は, 硫酸がばいじんに加えられることになる。硫酸ミス トは，一般のばいじん以上に危険な大気污染物質である から、ばいじんに加觉られても構わないといら論議もあ るが，厳密にばいじんを評価する上では問題である。今 後, ボイラ排ガス処理に，い特う酸化物をばいじんとあ わせて処理する目的で, 湿式処理法が普及することが予 想され，このことは別に論ずべき重要な課題である。
1）昭和46年版 公害白書 大蔵省印刷局発行, 41, (1971)

2）田森行男, 白沢忠雄; 粉体工学研究会誌, 8, 1, 8, (1971)
3）田森行男, 小暮信之, 今上一成; 公害と対策, $7,5,435$, (1971) 